\title{
The Effect of Shade and Planting Depth on the Emergence of Fourwing Saltbush
}

\author{
J.T. HENNESSY, R.P. GIBBENS, AND M. CARDENAS
}

\begin{abstract}
Planting trials in southern New Mexico with fourwing saltbush seeds on mesquite dunes and on shaded and nonshaded interdune areas during 3 successive years revealed that seedling emergence was always greater on shaded areas. Planting depth (2 and $5 \mathrm{~cm}$ ) did not appear to be a critical factor in seedling emergence. The shade provided by mesquite canopy explains, in part, why fourwing saltbush occurs with much higher frequency on dunes than on interdune areas.
\end{abstract}

In southern New Mexico, where mesquite (Prosopis glandulosa Torr.) dunes are common, fourwing saltbush [Atriplex canescens (Pursh) Nutt.] is characteristically found growing upon the dunes and rarely occurs on interdune areas. Densities of fourwing saltbush equivalent to 63 plants per hectare on dunes and only 2 plants per hectare on interdune areas have been found (Hennessy 1982). The unequal distribution of fourwing saltbush on dunes and interdunes may be due to a more favorable environment for germination on dunes where mesquite canopy provides shade and ameliorates soil temperatures. A field study was undertaken to evaluate the effect of shade upon the emergence of fourwing saltbush planted at 2 depths.

Germination of fourwing saltbush is usually best at relatively low temperatures $\left(<25^{\circ} \mathrm{C}\right)$ and is lower in the $25^{\circ} \mathrm{C}$ to $35^{\circ} \mathrm{C}$ range (Springfield 1970). Moisture stress decreases and delays germination, with a matric potential of $-2 \mathrm{MPa}$ being the effective limit for germination, especially at high temperatures (Osmond et al. 1980, Springfield 1970). Various seed treatments, including soaking, washing, and scarification of the seed coat, are not effective in enhancing germination, though breaking off the 4 wing-like bracts enclosing the seed (dewinging) seems to hasten germination slightly (Springfield 1970).

Seedlings usually begin emergence within 6 to 10 days after planting if soil water conditions permit. Spring and mid-summer seedings are usually more successful than fall seeding in the Southwest, especially if shade is available for the seedlings (Springfield 1970, Wilson 1928). In sandy loam soils, Springfield (1970) recommended a planting depth of less than $2.5 \mathrm{~cm}$ for best germination. Wilson (1928) recommended planting depths of 0.6 to 3.8 $\mathrm{cm}$ in sandy loam or gravelly sandy loam soils.

\section{Methods}

The study was conducted on an area of mesquite duneland on the Jornada Experimental Range (administered by the USDA, Agricultural Research Service), Dona Ana County, New Mexico. The study site was a 1-ha exclosure where interdune soils are coarse-loamy, mixed thermic, Typic Haplargids of the Onite series.

\footnotetext{
Authors are former graduate student, Department of Animal and Range Sciences, New Mexico State University, Las Cruces, now range research officer, Gaborone, Botswana, Africa; range scientist, U.S. Department of Agriculture, Agricultural Research Service, Las Cruces, N. Mex.; and associate professor, Department of Experimental Statistics, New Mexico State University, Las Cruces, respectively.

This article is published as Journal Article 934, Agricultural Experiment Station, New Mexico State University, Las Cruces.

Manuscript received April 23, 1982.
}

Soils of the mesquite dunes, which are up to $1.5 \mathrm{~m}$ in height, are mixed Typic Torripsamments of the Pintura series. Long-term average annual rainfall for the area is $230 \mathrm{~mm}$. The mean annual temperature is $15^{\circ} \mathrm{C}$. Average maximum temperatures are highest in June $\left(36^{\circ} \mathrm{C}\right)$ and lowest in January $\left(13.3^{\circ} \mathrm{C}\right)$.

Within the exclosure, 10 dunes and 20 interdune sites were chosen. Five of the dunes had a slope length of about $2 \mathrm{~m}$ and the other 5 had a slope length of about $1 \mathrm{~m}$. Using a wedge-shaped frame, with the apex of the wedge centrally located at the dune top, 2 random positions were marked with small stakes on each cardinal dune exposure. Two positions were marked in a $10-\mathrm{cm}$ radius circle on the dune tops. On the flat interdune sites the frame was used to lay out crosses with the arms oriented in the cardinal directions. Half of the crosses had arms $2 \mathrm{~m}$ in length and half had arms $1 \mathrm{~m}$ in length. Random positions were marked within the arms and at the centers as on the dunes. Half of the interdune sites were shaded by a horizontal snowfence with evenly spaced wooden slats (approximately $50 \%$ coverage) supported $40 \mathrm{~cm}$ above the soil surface. Ocular estimates of mesquite canopy cover over the dune planting sites showed a range of 10 to $90 \%$ cover with an average cover of $47 \%$ for all dune sites.

The first planting was made with fourwing saltbush seed collected at Los Lunas, N. Mex., (F-8A Los Lunas Pure) in 1973. Germination tests were made in 1979 after washing the dewinged seeds in water for $2 \mathrm{hr}$ to remove water-soluble inhibitors. The seeds were then placed on moist blotters at $15^{\circ} \mathrm{C}$ and the number germinating determined at weekly intervals for a total of 4 weeks (personal communication, Terry Turner, State Seed Analyst).

On August 2, 1979, at one of each pair of marked positions on dunes and interdunes, 10 seeds were buried at a depth of $2 \mathrm{~cm}$ and at the other position 10 seeds were buried at a depth of $5 \mathrm{~cm}$. After planting, the plots were checked daily and the numbers of emerged seedlings recorded until emergence ceased. The data were analysed using chi-square analyses for independence (Steel and Torrie 1960 ). The $P<0.05$ level was accepted as significant.

In February, 1980, native fourwing saltbush seeds were gathered on the study site. The germination rate, determined as previously described, was 35\%. On March 3, 1980, all of the plots were seeded using the locally collected seed. Prior to seeding each marker stake was relocated $10 \mathrm{~cm}$ south of its original position. The native seed was used for another planting made on February 27, 1981.

Some relevant soil temperatures were obtained with a data acquisition system maintained in the exclosure for another project. Copper-constantan thermocouples were buried at a depth of $5 \mathrm{~cm}$ on the cardinal exposures of a dune and at depths of 2 and $5 \mathrm{~cm}$ on an unshaded interdune site. All soil temperatures reported are the hourly averages of temperature sensings made at 5-min intervals.

\section{Results and Discussion}

Seedlings began to emerge on August 21 following the August 2, 1979 , planting. This followed an unusual event of rainfall on 7 consecutive days which totaled $68 \mathrm{~mm}$. No emergence occurred after September 6. The number of seedlings which emerged on 
Table 1. Number of fourwing saltbush seedlings which emerged following the August 2,1979 planting on dunes and nonshaded and shaded interdune areas from 2-and 5-cm planting depths by position (direction).

\begin{tabular}{|c|c|c|c|c|c|c|c|c|c|c|c|}
\hline \multirow[b]{3}{*}{ Site } & \multicolumn{10}{|c|}{ Number of Seedlings } & \multirow[b]{3}{*}{ Totals } \\
\hline & \multicolumn{5}{|c|}{ 2-cm depth } & \multicolumn{5}{|c|}{ 5-cm depth } & \\
\hline & South & East & North & West & Center & South & East & North & West & Center & \\
\hline Dune & 13 & 4 & 15 & 10 & 10 & 12 & 7 & 7 & 21 & 9 & 108 \\
\hline $\begin{array}{l}\text { Nonshaded } \\
\text { interdune } \\
\text { Shaded }\end{array}$ & 10 & 10 & 7 & 7 & 6 & 2 & 1 & 3 & 4 & 2 & 52 \\
\hline Interdune & 15 & 17 & 15 & 15 & 20 & 6 & 8 & 11 & 6 & 6 & 119 \\
\hline
\end{tabular}

dunes and shaded interdunes was twice the number emerging on nonshaded interdunes (Table 1).

Initial analysis of the data shown in Table 1 indicated that not all of the variables in the experiment were independent $\left(\chi^{2}=33.6\right)$. A test for independence between planting site (dunes, nonshaded and shaded interdunes) and position (direction) showed that there was no dependence or an association $\left(\chi^{2}=10,1\right)$. A test for independence between planting sites and planting depths showed that independence was not rejected $\left(\chi^{2}=17.1\right)$. Planting depths on dunes had no influence on emergence (2-cm depth 52 seedlings; $5-\mathrm{cm}$ depth, 56 seedlings). When compared with dunes, independence of planting depth was not rejected for either shaded interdunes $\left(\chi^{2}=10.1\right)$ of non-shaded interdunes $\left(\chi^{2}=11.9\right)$. There were significantly more seedlings emerging from the $2-\mathrm{cm}$ depth on interdunes (40 nonshaded, 82 shaded) than from the 5-cm depth (12 nonshaded, 37 shaded). Since independence was rejected when shaded and nonshaded interdunes and planting depths were compared $\left(\chi^{2}=1.1\right)$, the two interdune sites did not differ significantly in numbers of seedlings emerging from the 2 depths.

Following the March 3, 1980, planting, no precipitation was received until May 3, when $43 \mathrm{~mm}$ fell. This single rainfall event caused some germination but the numbers of seedlings which emerged were too small for inferential analysis. Shaded interdunes did have more seedlings emerge (48) than nonshaded interdunes (3) or dunes (7). There was little difference in the number of seedlings which emerged from the 5-cm depth (31) and from the 2-cm depth (27).

Germination of the February 27, 1981, planting was triggered by $20 \mathrm{~mm}$ of precipitation received on March 2. As in 1980, few seedlings emerged. More seedlings emerged on dunes (22) than on shaded interdunes (1) or nonshaded interdunes (2). There was little difference in the numbers of seedlings which emerged from the

Table 2. Maximum and minimum soil temperatures $\left({ }^{\circ} \mathrm{C}\right.$ ) recorded on nonshaded interdune and dune exposures over various dates in 1980 and 1981. Temperatures are hourly averages of temperature sensings made at 5-min intervals.

\begin{tabular}{|c|c|c|c|c|c|c|}
\hline \multirow[b]{2}{*}{ Site } & \multirow[b]{2}{*}{ Depth } & \multirow[b]{2}{*}{ Exposure } & & \multicolumn{3}{|c|}{ Temperature in ${ }^{\circ} \mathrm{C}$ on dates of measurement } \\
\hline & & & & $\operatorname{Mar} 3 \& 4,1981$ & May 3 to 10,1980 & Aug 26 to 28,1980 \\
\hline $\begin{array}{l}\text { Nonshaded } \\
\text { Interdune }\end{array}$ & $2 \mathrm{~cm}$ & & $\begin{array}{l}\text { Max } \\
\text { Min }\end{array}$ & $\begin{array}{r}23 \\
3\end{array}$ & $\begin{array}{r}36 \\
9\end{array}$ & $\begin{array}{l}50 \\
16\end{array}$ \\
\hline $\begin{array}{l}\text { Nonshaded } \\
\text { Interdunc }\end{array}$ & $5 \mathrm{~cm}$ & & $\begin{array}{l}\text { Max } \\
\text { Min }\end{array}$ & $\begin{array}{r}23 \\
3\end{array}$ & $\begin{array}{r}33 \\
9\end{array}$ & $\begin{array}{l}42 \\
17\end{array}$ \\
\hline \multirow[t]{5}{*}{ Dune } & $5 \mathrm{~cm}$ & North & $\begin{array}{l}\text { Max } \\
\text { Min }\end{array}$ & $\begin{array}{r}11 \\
5\end{array}$ & $\begin{array}{l}24 \\
10\end{array}$ & $\begin{array}{l}29 \\
20\end{array}$ \\
\hline & & West & $\operatorname{Max}$ & 17 & 30 & 36 \\
\hline & & & Min & 5 & 10 & 18 \\
\hline & & South & $\begin{array}{l}\operatorname{Max} \\
\operatorname{Min}\end{array}$ & $\begin{array}{r}23 \\
5\end{array}$ & $\begin{array}{l}30 \\
10\end{array}$ & $\begin{array}{l}37 \\
20\end{array}$ \\
\hline & & East & $\begin{array}{l}\text { Max } \\
\text { Min }\end{array}$ & $\begin{array}{r}15 \\
5\end{array}$ & $\begin{array}{l}26 \\
10\end{array}$ & $\begin{array}{l}33 \\
20\end{array}$ \\
\hline
\end{tabular}

2-cm depth (14) and from the 5-cm depth (11).

The greater number of seedlings emerging from the 2-cm depth on interdune areas in 1979 supports the findings of Springfield (1970) and Wilson (1928) that shallower planting depths promote the germination of fourwing saltbush. However, the lack of difference in emergence from 2- and 5-cm depths on dunes in 1979 and the nearly equal numbers of seedlings emerging from the 2 depths in 1980 and 1981 indicate that planting depth may not be a critical factor for seedling emergence in the mesquite dune habitat.

At a depth of 0 to $15 \mathrm{~cm}$ the interdune soils are $79 \%$ sand, $6 \%$ silt, and $15 \%$ clay. At the same depth, the dune soils are $88 \%$ sand, $2 \%$ silt, and $10 \%$ clay. With more silt and clay, the interdune soils have a higher water retention capacity than the dune soils (Brady 1974), and seed germination should be favored on interdune areas. However, the scarcity of fourwing saltbush on the interdune areas indicates that factors other than soil water retention are operative.

Soil temperatures were recorded on a few days during the period of seedling emergence in March, 1981, and May, 1980 (Table 2). The soil temperatures in early March, 1981, appear to be favorable $\left(<25^{\circ} \mathrm{C}\right)$ for germination of fourwing saltbush on both dunes and interdunes. At this time mesquite leaves had not emerged and the only shade on the dunes was that provided by the bare stems. In early May, 1980, maximum soil temperatures at the 5 -cm depth on the nonshaded interdune $\left(33^{\circ} \mathrm{C}\right)$ and south $\left(30^{\circ} \mathrm{C}\right)$ and west $\left(30^{\circ} \mathrm{C}\right)$ dune exposures were in the range where Springfield (1970) found reduced germination of fourwing saltbush. The full shading effect of the mesquite canopy had not been reached in early May because the mesquite leaves continued to grow until May 25 (unpublished phenology data). in August, 1979. Records from the Jornada Experimental Range
Due to equipment failures, no soil temperatures were obtained 
weather station (USDC 1979, 1980) show that average maximum air temperatures for the August 20 to 31 period were very similar in $1979\left(33.2^{\circ} \mathrm{C}\right)$ and $1980\left(32.9^{\circ} \mathrm{C}\right)$. Thus the soil temperatures recorded for August 26 to 28, 1980 (Table 2) give some indication of what soil temperatures might have been in 1979. The high maximum temperatures reached on the nonshaded interdune at the 2-cm depth $\left(50^{\circ} \mathrm{C}\right)$ and $5-\mathrm{cm}$ depth $\left(42^{\circ} \mathrm{C}\right)$ is probably the reason that seedling emergence was lower on nonshaded than on shaded areas. The relatively small differences in maximum soil temperatures on the cardinal dune exposures in August (Table 2) may be the reason for lack of significant differences in seedling emergence on dune exposures. The soil temperature data indicate that dunes, with consistently lower maximum temperatures and a smaller spread between maximum and minimum temperatures, have a more favorable environment for germination of fourwing saltbush than nonshaded interdunes.

There appears to be some relationship between the amount of rainfall which triggers germination of fourwing saltbush and the number of seedlings emerging. In 1979, 279 seedlings emerged following $68 \mathrm{~mm}$ of rainfall spread over 7 days. In 1980, 58 seedlings emerged following a $43-\mathrm{mm}$ rainfall event. Only 25 seedlings emerged following a $20 \mathrm{~mm}$ rainfall event in 1981 . Long-term rainfall records show that July, August, and September are the months of greatest rainfall. This period of maximum rainfall probability also coincides with maximal soil temperatures. Thus, it is highly probable that the shade provided by mesquite canopy increases the chances for the germination of fourwing saltbush on dunes. The relatively sparse stands of grasses and forbs on the interdune areas provide few shaded microsites where fourwing saltbush seeds would have a higher probability of germinating. In the spring months, soil temperatures are more favorable for germination on both dunes and interdunes but the probability of effective rainfall is low.

\section{TWO WILDLIFE \\ FACULTY POSITIONS}

Assistant/Associate Professor of Wildlife Management: The Department of Range and Wildlife Management at Texas Tech University seeks to fill two teaching/research positions. One position will be filled on January 1, 1984, and other position will be filled on July 15, 1984. Teaching responsibilities for each position will include some combination of Big Game Ecology, Upland Game Ecology, Wildlife Techniques, Wildlife Population and Dynamics, Wildlife Physiological Ecology, and Introductory Wildlife. Please indicate your strengths and preferences in a resume. Each faculty member will have 3 or 4 courses to teach per year. A diversity of research interests and backgrounds adaptable to West Texas will be considered. Send resume, transcripts, and a statement of teaching and research interests, and three letters of reference to: Dr. Henry A. Wright, Chairperson, Department of Range and Wildlife Management, P.O. Box 4169, Texas Tech University, Lubbock, Texas 79409. Review of applications for the January position will be December 1, 1983 and review of applications for the July position will be April 1, 1984. Texas Tech University is an affirmative action/equal opportunity employer.
These planting trials indicate that mesquite canopy shade may be one factor contributing to greater saltbush density on dunes. However, other factors may also play a role. It is known that rodents found in the mesquite dune areas cache seeds in their burrows (Wood 1969), and it is quite possible that fourwing saltbush plants may originate from seeds concentrated by the rodents. Rodent burrows are common in the dunes but are rarely found in interdune areas.

Of all the seedlings which emerged during the 3 years, none lived for more than a few months. It is apparent that, in this arid climate, fourwing saltbush germination may be triggered by small rainfall events in either spring or summer. However, the seedlings will become established only in years with very favorable rainfall patterns.

\section{Literature Cited}

Brady, N.C. 1974. The Nature and Properties of Soils, 8 th ed. MacMillan Pub. Co., Inc., New York.

Hennessy, J.T. 1982. Mesquite (Prosopis glandulosa Torr.) dunes and interdunes in southern New Mexico: A study of water relations and plant production. Ph.D. Diss., New Mexico State University, Las Cruces.

Osmond, C.B., O. Bjorkman, and D. Anderson. 1980. Physiological Processes in Plant Ecology: Toward a Synthesis with Atriplex. SpringerVerlag. New York.

Springfield, H.W. 1970. Germination and establishment of fourwing saltbush in the Southwest. USDA Forest Serv. Res. Pap. RM-55. G.P.O., Washington.

Steel, R.G.D. and J.H. Torrie. 1960. Principles and Procedures of Statistics. McGraw-Hill Book Co., Inc., New York.

U.S. Department of Commerce. 1979. National Oceanic and Atmospheric Administration. Climatological Data, New Mexico. Vol. 83.

U.S. Department of Commerce. 1980. National Oceanic and Atmospheric Administration. Climatological Data, New Mexico. Vol. 84.

Wilson, C.P. 1928. Factors affecting the germination and growth of chamiza (Atriplex canescens). N. Mex. Agr. Exp. Sta. Bull. 169. Las Cruces.

Graduate Research Assistantship: Full-time, M.S. level assistantship in the growth and development of Lehmann lovegrass. The study will include the effects of seasonal fire application on the above- and below-ground productivity of Lehmann lovegrass.

Bachelor degree required. A strong background in soils, plant ecology biochemistry, plant physiology and plant morphology is desirable.

Submit a resume, complete transcript and three letters of recommendation to:
Dr. Jerry Cox
or
USDA-ARS
Dr. George Ruyle
Arid Land Ecosystems
Improvement
Department of Renewable
2000 E. Allen Rd.
Natural Resources
Tucson, AZ 85719
University of Arizona
Tucson, AZ 85721
(602) 621-1384

(602) 629-6881 